\title{
UPAYA MENINGKATKAN KREATIVITAS BELAJAR BIOLOGI SISWA MELALUI PENERAPAN MODEL PEMBELAJARAN KOOPERATIF TIPE NUMBER HEAD TOGETHER (NHT) DI MAN SIABU
}

\author{
Arni Maya ${ }^{1)}$, Nurmaini Ginting ${ }^{1)}$, Sahlan Tuah ${ }^{1)}$ \\ ${ }^{1)}$ Program Studi Biologi, Fakultas Keguruan dan Ilmu Pendidikan, Universitas Muhammadiyah Tapanuli Selatan, \\ Indonesia \\ e-mail:nurmaini.ginting@um-tapsel.ac.id
}

\begin{abstract}
Abstrak
Masalah yang dihadapi adalah kurangnya minat siswa, hal ini disebabkan mata pelajaran biologi membuat siswa mudah bosan dan menganggap mata pelajaran biologi adalah salah satu pelajaran yang sulit. Pada saat observasi guru lebih mendominasi dalam proses pembelajaran, sehingga kreativitas siswa kurang. Diperlukan model pembelajaran yang model pembelajaran yang sesuai sehingga mampu untuk meningkatkan kreativitas siswa dalam mencetuskan gagasan, jawaban, penelesaian masalah atau pertanyaan, keterampilan dalam melihat masalah dari sudut pandang yang berbeda - beda, kemampuan melahirkan ungkapan yang baru dan unik dan mampu meningkatkan kemampuan siswa dalam hal keterampilan atau mengembangkan gagasan siswa dalam proses pembelajaran. Jenis penelitian adalah penelitian tindakan kelas dengan Model pembelajaran kooperatif tipe Number Head Together (NHT). Hasil siklus I hasil tes kreativitas siswa 78,94\% sementara pada siklus II mengalami peningkatan 5,27\% dengan hasil persentase $84,21 \%$, hasil observasi pada siswa di siklus I menunjukkan hasil 65,27\% mengalami peningkatan 10,45\% dalam siklus II dengan hasil persentase 75,72\% dan hasil observasi terhadap aktivitas guru di siklus I diperoleh $72 \%$ pada siklus kedua mengalami peningkatan sebanyak 16\% menjadi 88\%.Dari penelitian ini diperoleh kesimpulan bahwa melalui model pembelajaran Number Head Together (NHT) dapat meningkatkan kreativitas siswa kelas XI MIA 2 MAN Siabu.
\end{abstract}

Kata kunci: Kreativitas, Number Head Together, Penelitian tindakan kelas

\begin{abstract}
The problem faced is the lack of student interest; this is because biology subjects make students easily bored and assume biology is one of the difficult subjects. At the time of observation the teacher is more dominant in the learning process, so students' creativity is lacking. Learning models are needed that are appropriate learning models so as to be able to increase student creativity in sparking ideas, answers, solving problems or questions, skills in seeing problems from different points of view, the ability to give birth to new and unique expressions and able to improve students' abilities in terms of skills or develop students' ideas in the learning process. This type of research is classroom action research with a Number Head Together (NHT) type of cooperative learning model. The results of the first cycle students' creativity test results $78.94 \%$ while in the second cycle increased $5.27 \%$ with a percentage of $84.21 \%$, the results of observations on students in the first cycle showed the results of $65.27 \%$ experienced an increase of $10.45 \%$ in the cycle II with the results of a percentage of $75.72 \%$ and the results of observations of the activities of teachers in the first cycle obtained $72 \%$ in the second cycle increased by $16 \%$ to $88 \%$. From this study it was concluded that through the Number Head Together (NHT) learning model can increase creativity Grade XI student MIA 2 MAN Siabu.
\end{abstract}

Keywords: Creativity, Number Head Together, Classroom Action Research

PeTeKa (Jurnal Penelitian Tindakan Kelas dan Pengembangan Pembelajaran) $\mid 1$ 


\section{PENDAHULUAN}

Seorang guru Biologi berperan penting dalam dalam meningkatkan kreativitas belajar siswa agar dapat meningkatkan mutu pembelajarannya melalui pemanfaatan lingkungan yang ada.Adapun yang menjadi masalah adalah bagaiman usaha guru tersebut untuk meningkatkan kreativitas belajar siswa.

Supriadi dalam Rachmawati (2005) berpendapat bahwa kreativitas adalah kemampuan sesorang untuk melahirkan sesuatu yang baru, baik berupa gaagasan, maupun sebuah karya nyata yang relatif berbeda dengan apa yang telah ada. Diharapkan gagasan yang disampaikan dapat digunakan sebagai acuan dalam pemecahan masalah .

Siswa yang memiliki kreativitas dalam proses belajar memiliki dorongan rasa ingin tahu yang tinggi ditandai dengan seringnya siswa mempelajari pelajaran yang belum disampaikan oleh guru, demikian juga dalam belajar siswa sering mengajukan pertanyaan, sering mengajukan gagasan dan usul terhadap suatu masalah tentang materi yang diajarkan dan siswa juga diberi kebebasan dalam menyatakan pendapatnya.

$$
\text { Menurut Semiawan dalam }
$$

Suryosubroto (2009) mengatakan bahwa siswa yang memiliki kreatif adalah siswa yang sering mengajukan pertanyaan yang baik, memberikan banyak gagasan atau usul terhadap masalah, bebas dalam menyampaikan suatu pendapat, menonjol dalam salah satu bidang seni, mempunyai pendapat sendiri dan dapat mengungkapkannya, tidak mudah terpengaruhi orang lain, daya imajinasi kuat, originalitas tinggi (hal ini dilihat dalam pengungkapan gagasan, karangan dan sebagainya dan menggunakan cara cara orisinil dalam pemecahan masalah) dapat bekerja sendiri ataupun bekerja sama dan senang mencoba hal - hal yang baru.

Berdasarkan hasil wawancara dengan seorang guru yang membawakan mata pelajaran Biologi di kelas XI MIA 2 MAN Siabu menyatakan bahwa dalam proses penyampaian materi pelajaran lebih sering menggunakan model pembelajaran kooperatif tipe CTL dengan menggunakan metode demonstrasi kemudian memberikan beberapa pertanyaan kepada siswa.

Kegiatan belajar mengajar di kelas XI MIA 2 yang menggunakan model CTL ternyata tidak mampu meningkatkan kreativitas dari siswa. Hal ini sesuai dengan Trianto (2010) mengatakan bahwa model CTL memiliki kelemahan dimana penerapan pembelajaran kontekstual merupakan pembelajaran yang kompleks dan sulit dilaksanakan dalam konteks pembelajaran dan membutuhkan waktu yang lama. Sehingga kecakapan dari guru maupun siswanya terminimalisir pengoptimalan dalam proses pelaksanaannya.

Selanjutnya peneliti melaksanakan observasi kreativitas belajar siswa terlihat kenyataan dalam proses belajar siswa diperoleh hasil bahwa siswa kurang memiliki pengetahuan mendalam dibuktikan dengan masih jarang siswa mengajukan pertanyaan terhadap materi yang diberikan, siswa juga tidak banyak memiliki gagasan dan usul terhadap suatu masalah, demikian juga dalam belajar siswa tidak memiliki kebebasan untuk menyatakan pendapat disebabkan guru masih lebih dominan dalam pembelajaran. Hasil sebaran angket terhadap siswa yang sesuai dengan indikator dari kreativitas seperti pada indikator keterampilan berpikir secara lancar siswa masih dalam kuaifikasi kurang dengan perolehan angka 2,7. Pada indikator yang kedua pada aspek berpikir luwes dengan hasil kualifikasi kurang dengan angka 2,8. Pada indikator ketiga aspek keterampilan berpikir orisinil kualifikasi yang diraih siswa pun kurang dengan angka 2,6 dan pada indikator ke empat pada aspek keterampilan dalam memperinci (mengelaborasi) diperoleh hasil dengan kualifikasi kurang dengan angka 2,8. 
Maka dapat disimpulkan bahwa kreativitas siswa masih kurang berdasarkan perolehan keseluruhan indikator adalah kurang dengan angka rata-rata 2,7 dikatakan dia kurang pada angka tersebut berdasarkan skala penghitungan yang di terapkan adalah skala 4.

Kemampuan menjawab soal siswa kelas XI MIA 2 MAN SIABU dalam pelakasanaan ulangan dari 38 orang siswa 11 orang dengan persentasi 28,94\% dikatakan tuntas dengan sangat baik,dan siswa yang tuntas dengan kategori baik ada 9 orang dengan persentasi 23,68\%, siswa yang dikatakan tuntas dengan kategori cukup ada 18 orang dengan persentasi 47,36\% sehingga dapat disimpulkan hasil tes kemampuan siswa cukup dan rata - rata siswa di kelas XI MIA 2 mampu menjawab tes yang telah diberikan kepada mereka dengan KKM 86 .

Dari hasil observasi aktivitas guru dalam proses pembelajaran pada kegiatan inti yang dilakukan di peroleh hasil bahwa pembelajaran yang dilakukan sesuai dengan langkah - langkah dari model pembelajaran yang diterapkan, dimana terlihat guru memberikan ruang kepada siswa untuk bertanya dan menyampaikan pendapat - pendapatnya secara luas, namun dalam hal ini masih ada sebagian siswa yang tidak bertanya dengan baik. Hal ini dapat dilihat dalam perolehan tes ulangan harian siswa dalam tabel di atas.

Ulfaira (2018) menyatakan bahwa kreativitas penting dalam membuat kombinasi baru berdasarkan data, informasi atau unsur yang ada. Dijelaskan juga bahwa data atau informasi yang tersedia tersebut memungkinkan suatu jawaban terhadap berbagai permasalahan yang ada dan penekanannya pada kualitas atau mutu, ketata penggunaan dan keragaman jawaban. Dengan demikian dapat dikatakan bahwa kreativitas seseorang akan mencerminkan keluwesan, kelancaran dan originalitas seseorang dalam berpikir serta membuat seseorang memiliki kemampuan dalam megelaborasi suatu gagasan.

Upaya meningkatkan kreativitas belajar siswa adalah dengan memilih model pembelajaran yang sesuai sehingga mampu untuk meningkatkan kreativitas siswa dalam mencetuskan gagasan, jawaban, penelesaian masalah atau pertanyaan, keterampilan dalam melihat masalah dari sudut pandang yang berbeda - beda, kemampuan melahirkan ungkapan yang baru dan unik dan mampu meningkatkan kemampuan siswa dalam hal keterampilan atau mengembangkan gagasan siswa dalam proses pembelajaran. Salah satu model pembelajaran yang bisa digunakan dalam pengembangan kreativitas siswa adalah model pembelajaran kooperatif tipe Number Heads Together (NHT).

Model pembelajaran NHT pada dasarnya merupakan varian diskusi kelompok, memberikan kesempatan kepada siswa untuk membagikan ide dan mempertimbangkan jawaban yang paling tepat serta mendorong siswa untuk meningkatkan semangat kerja sama mereka (Sulfiani, 2016; Adang dkk., 2012).

Penerapan model pembelajaran ini adalah pembelajaran yang sepenuhnya melibatkan siswa dalam pembelajarannya, dimana masing - masing siswa disini di beri nomor yang berbeda meskipun dalam satu kelompok yang sama. Dan dalam model ini siswa menyatukan pendapatnya dalam memecahkan masalah yang diberikan kepada kelompoknya sehingga bias meningkatkan kreativitas siswa.

\section{METODE}

Jenis penelitian ini adalah penelitian tindakan kelas dengan menggunakan model pembelajaran Number Head Together (NHT) pada materi respirasi. Penelitian ini dilakukan dalam 2 (dua) siklus. Setiap siklus terdiri atas 4 tahap yaitu perencanaan (planning), pelaksanaan 
PeTeKa (Jurnal Penelitian Tindakan Kelas dan Pengembangan Pembelajaran)

Vol 2 No 1 Tahun 2019 Hal 1-8

(acting), pengamatan (observation), dan refleksi (reflection). Alat pengumpul data adalah lembar tes dan lembar observasi.

\section{Analisis Data}

1. Analisis Data Tes Kreativitas

a. Menentukan Mean

$$
\begin{aligned}
& \text { Mean }=\mathrm{MT}+\mathrm{i} \stackrel{\sum f d}{(N)} \\
& \text { Keterangan : } \\
& \mathrm{MT}=\text { Mean Terkaan } \\
& € f d=\begin{array}{l}
\text { Jumlah hasil kali dengan deviasi } \\
\text { dugaan }
\end{array} \\
& \mathrm{N}=\text { Jumlah siswa }
\end{aligned}
$$

b. Menghitung Nilai maksimum dan minimum

c. Menghitung tentang data (range)

$\mathrm{R}=\mathrm{xt}-\mathrm{xr}$

Keterangan :

$\mathrm{R}$ = rentang

$\mathrm{Xt}=$ skor tertinggi

$\mathrm{Xr}=$ skor rendah

Setiap lembar jawaban siswa dikoreksi untuk mengetahui kreativitas belajar biologi siswa.Untuk mengetahui tingkat kreativitas belajar biologi siswea diperoleh dengan menggunakan rumus skala 5 yang berpedoman pada acuan relatif.

\section{Analisis Data hasil observasi}

Analisis data observasi pengelolaan kegiatan model Number Head Together (NHT) aktivitas peserta didik dan data pengolahan observasi di peroleh dari pengolahan pembelajaran. Data analisis dengan menghitung rata-rata setiap aspek dari berapa kali pertemuan yang dilaksanakan selanjutnya nilai rata-rata tersebut di refleksi.

Data hasil pengamatan kreativitas selama kegiatan pembelajaran dianalisis berdasarkan persentasi. Persentasi kreativitas siswa yaitu frekuwensi setiap aspek pengamatan dibagi dengan jumlah frekuensi semua aspek pengamatan dikali $100 \%$.

$\%$ aktivitas siswa $=\frac{\text { frekuensi setiap aspek pengamatan }}{j \text { jumlah frekuensi semua aspekpengamatan }} \times 100 \%$

3. Analisis data kemampuan guru mengelola pembelajaran

Dari hasil pengamatan aktivitas guru selama kegiatan pembelajaran dianalisis berdasarkan presentasi, presentasi aktivitas guru yaitu frekuensi setiap aspek dengan jumlah sema aspek pengamatan di kali $100 \%$

$\%$ aktivitas guru $=\frac{\text { frekunnsi setiap aspek pengamatan }}{\text { jumlah frekunnsi semua aspekpenganatan }} \times 100 \%$

4. Indikator Kinerja

Dalam PTK ini yang indikator kinerjanya selain siswa adalah guru, karena gurur merupakan fasilisator yang sanagt berpengaruh terhadap kinerja siswa.

\section{HASIL DAN PEMBAHASAN}

A. Hasil Penelitian

1. Hasil penelitian siklus I

Siklus I dilaksanakan dalam 2 kali pertemuan. Dimana masing - masing pertemuan 2 jam pelajaran ( 2 x 45 menit) di kelas XI MIA 2 MAN Siabu.

\section{a. Hasil Tes Kreativitas Siklus I}

Jumlah siswa yang memperoleh kualifikasi nilai sangat baik dengan berpatokan kepada mean 95 ke atas berjumlah 20 orang, dan kualifikasi nilai baik dengan patokan nilai 81,5 s/d 94,5 berjumlah 12 orang dan kualifikasi cukup nilai 66,5 s/d 80,5 berjumlah 4 orang, dan kualifikasi kurang dengan nilai 51,5 s/d 65,9 berjumlah 1 orang, dan kualifikasi nilai 50,5 kebawah berjumlah 1 orang. Hasil yang di peroleh dari tes adalah 78,94\% dengan kategori persentasi cukup baik.

Setiap indikator kreativitas hasilnya sangat baik di mana pada indikator 1 diperoleh angka rata - rata sebesar 6,1 pada indikator ke 2 diperoleh angka 11,0, pada indikator ke 3 diperoleh angka rata - rata 9,2 sedangkan pada indikator ke 4 di peroleh angka 9,0 dengan rata - rata keseluruhan indikator di peroleh angka 8,8 degan kualifikasi sangat baik dimana lebih jelasnya 
dapat di perhatikan pada gambar 1.

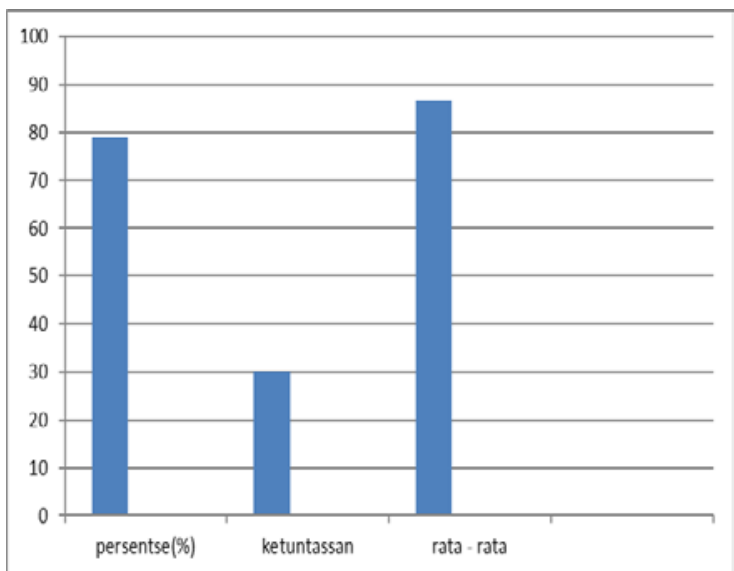

Gambar 1. diagram hasil perolehan tes kreativitas siklus I

\section{b. Lembar Observasi Siswa dan Guru Siklus I}

Berdasarkan hasil lembar observasi kreativitas siswa di siklus I dapat disimpulkan bahwa aktivitas kreatif siswa masih cukup dengan perolehan persentase dari pertemuan pertama 33,17\% dan kedua $32,10 \%$ pada siklus I $65,27 \%$ dengan kualifikasi cukup. Hasil observasi kreativitas siswa dapat dilihat pada gambar 2 .

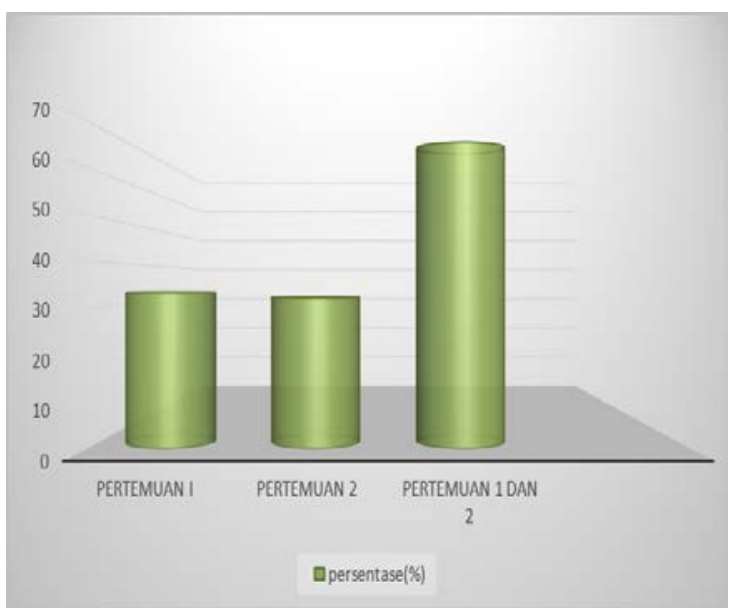

Gambar 2. hasil observasi aktivitas siswa siklus I

Selain mengamati semua aktivitas siswa observer juga harus mengamati semua aktivitas yang dilakukan guru mulai dari pembukaan sampai penutupan pembelajaran dan Hasil observasi kinerja guru dalam proses belajar mengajar.

Hasil observasi guru dalam proses belajar mengajar pada siklus I sudah sangat baik, dikarenakan pada pembelajaran sebelumnya dengan model yang berbeda guru sesekali membuat pembelajaran dengan berkelompok sehingga guru tidak begitu sulit untuk mengarah dan membimbing siswa dalam belajar kelompok, pencapaian dari hasil observasi ini di katakana cukup setelah melihat skala penilaian terhadap kemampuan guru dalam mengelola kelas jelasnya perhatikan gambar 3.

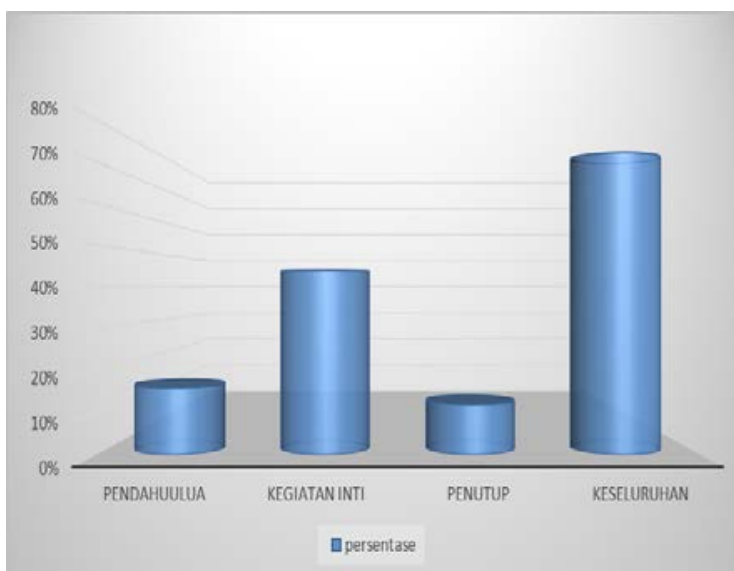

Gambar 3. Hasil Observasi Pengelolaan Kelas Siklus I

Adapun temuan peneliti pada pertemuan 1 dan pertemuan ke 2 pada siklus I , kreativitas siswa cukup baik di lihat dari hasil tes kreativitasnya dimana ynag mencapai KKM hanya 30 orang, hasil observasi terhadap aktivitas siswa pun masih cukup yaitu 65,27\% dan bisa jadi disebabkan siswa masih kurang terbiasa dengan model pembelajaran Number Head Together atau model ini masih baru dalam pembelajaran mereka, namun hasil observasi pada guru sudah baik dimana guru bisa menerapkan model ini dengan perolehan persentasi observasi guru 81,33\% dengan kategori baik. Berdasarkan hasil dan masalah yang di temuan peneliti pada siklus satu baik pada pertemuan 1 dan pertemuan 2 di harapkan kolaborasi antara guru dengan peneliti pada siklus berikutnya terlaksana dengan baik dan siswa sudah bisa beradaptasi dengan model pembelajaran ini sehingga hasil tes dan observasi terhadap aktivitas siswa sangat baik. Namun hasil yang diperoleh pada 
PeTeKa (Jurnal Penelitian Tindakan Kelas dan Pengembangan Pembelajaran)

Vol 2 No 1 Tahun 2019 Hal 1-8

siklus I belum mencapai indicator keberhasilan, sehingga penelitian dilanjutkan ke siklus II.

\section{Hasil penelitian siklus II}

\section{a. Hasil Tes Kreativitas Siswa Siklus II}

Hasil tes kreativitas pada siklus II siswa yang mencapai kualifikasi sangat baik dengan perolehan nilai 95 keatas berjumlah 20 orang, yang mencapai kualifikasi baik dengan perolehan nilai 81,5 s/d 94,5 berjumlah 15 orang, yang mencapai kualifikasi cukup dengan pencapaian angka 66,5 s/d 80,5 berjumlah 2 orang, yang mencapai kualifikasi kurang dengan nilai 51,5 s/d 65,9 berjumlah 0 orang dan yang mencapai kualifikasi sangat kurang dengan perolehan angka 50,5 kebawah berjumlah 1 orang.

Demikian halnya dengan hasil pencapaian siswa pada setiap indikator kreativitas mencapai angka 8,0 pada indikator 1 , pada indikator ke 2 mencapai angka 9,9 pada indikator ke 3 mencapai angka 9,8 dan pada indikator ke 49,7 dengan hasil rata - rata dari keseluruhan indikator adalah 9,4 dengan kualifikasi hasil sangat baik. Lebih jelasnya perhatikan gambar 4 .

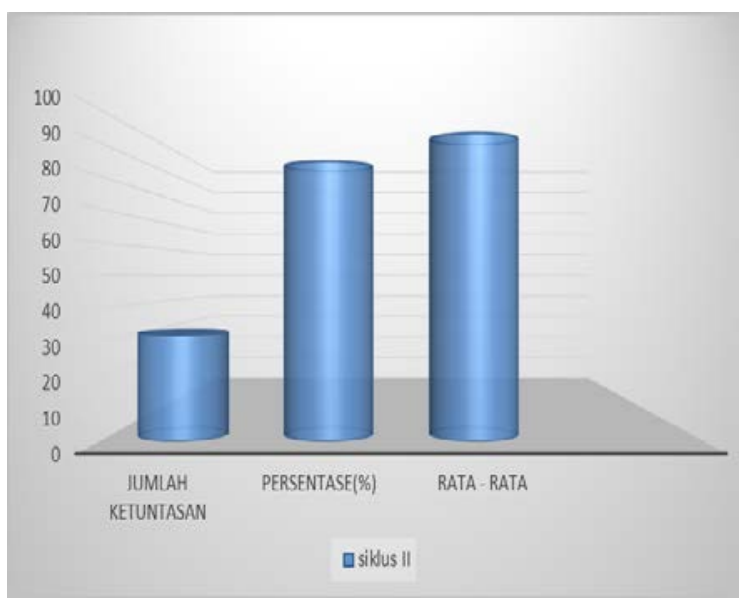

Gambar 4. Hasil Perolehan Hasil Tes Kreativitas Siswa Siklus II

\section{b. Lembar Observasi Siswa dan Guru Siklus II}

Selama proses belajar mengajar, peneliti sebagai seorang kolabolator guru yang mengajar dalam kelas memiliki peran aktif di dalam ruangan dimana peneliti menjadi seorang pengamat atas semua aktivitas yang dilakukan siswa selama mengikuti proses belajar mengajar.

Berdasarkan lembar observasi aktivitas siswa dapat disimpulkan bahwa aktivitas siswa sudah meningkat dari aktivitas siswa pada siklus I dimana pencapaian hasil observasi di siklus II ini sudah meningkat dilihat dari persentasi pertemuan pertama 34,68 \% pertama dan kedua $41,04 \%$ pada siklus II ini menjadi 75,72 \% dengan kualifikasi cukup,hal ini di sesuaikan dengan rujukan dalam penelitian yang mengklasifikasikan skala penelitian. Jelasnya perhatikan gambar 5 .

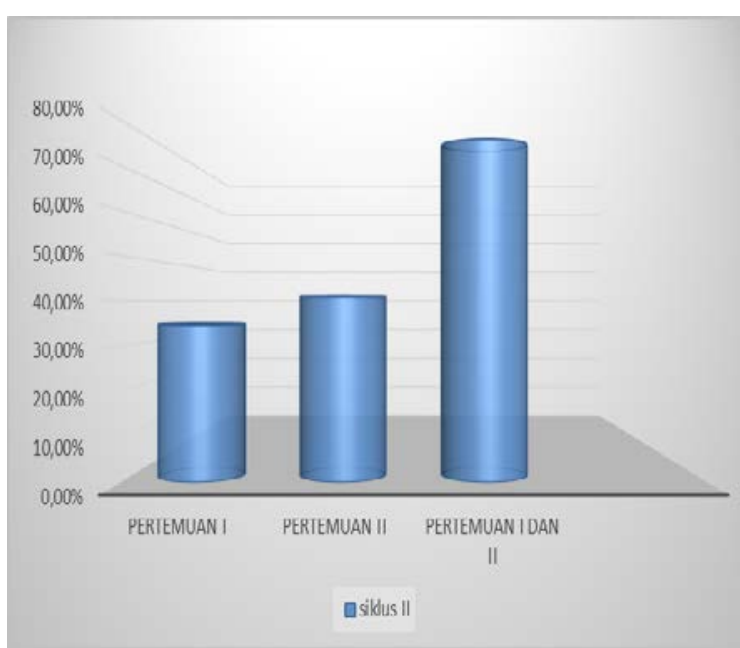

\section{Gambar 5. Hasil Observasi Aktivitas Siswa Siklus II}

Selain mengamati aktivitas siswa peneliti sebagai kolabolator juga harus mengamati aktivitas yang dilakukan oleh guru dalam pembelajaran dan Hasil observasi aktivitas kinerja guru dalam proses belajar mengajar.

Hasil wawancara dengan guru kelas XI menyatakan setelah menerapkan model pembelajaran NHT ini terhadap belajar siswa cukup mempengaruhi sikap dan kreatif siswa dalam belajar hal ini di lihat bagaimana siswa sangat antusias dalam mengerjakan tugas kelompoknya, dan yang pendiam di usahakan ikut terlibat juga dalam mengerjakan tugas dalam kelompoknya. 


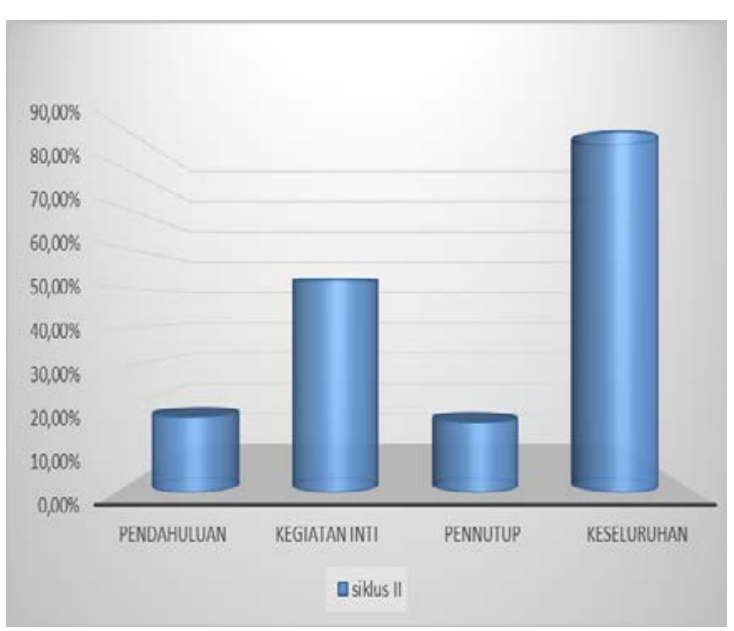

\section{Gambar 6. Hasil Observasi Aktivitas Guru Siklus II}

\section{B. Pembahasan}

\section{1) Kreativitas Siswa}

Berdasarkan hasil penelitian yang dirumuskan dalam pendahuluan serta paparan dari hasil penelitian dan berikut ini da;ah pemaparan dari hasil penelitian yang dilaksanakan dua Siklus di kelas XI MIA 2 MAN Siabu.

Tabel 1. Hasil Keseluruhan Tes
\begin{tabular}{|c|c|c|c|}
\hline Kreativitas Siswa \\
\hline 1 & Siklus & $\begin{array}{c}\text { Persentase } \\
\text { ketuntasan }\end{array}$ & Peningkatan \\
\hline 2 & Siklus I & $78,94 \%$ & \multirow{2}{*}{$5,27 \%$} \\
\hline
\end{tabular}

Dari tabel 1. dapat ditarik kesimpulan bahwa pada siklus I yang dilakukan 2 pertemuan berdasarkan tes kreativitas siswa masih rendah dimana dengaan rata - rata 86,63 yang tuntas hanya 30 orang dengan persentasi ketuntasan 78,94\% oleh karena itu perlu ditingkatkan lagi dengan dilanjutkannya penelitian ke siklus II. Pada siklus II terjadi peningkatan kreativitas siswa 5,27\%. Hal ini juga sesuai dengan hasil penelitian Khairunnisah (2018) mengatakan bahwa ditinjau dari rata - rata antara siklus I yang mengalami peningkatan setelah di lakukan tindakan lanjutan yaitu pada siklus II.

\section{2) Aktivitas Siswa}

Perbandingan hasil observasi aktivitas siswa pada siklus I dan siklus II baik itu pertemuan pertama sampai pertemuan terakhir dapat dilihat pada tabel 2 .

Tabel 2. Hasil Keseluruhan Observasi Aktivitas Siswa

\begin{tabular}{|l|l|l|}
\hline No & \multicolumn{1}{|c|}{ Siklus } & Persentase \\
\hline 1 & Siklus I & $65,27 \%$ \\
\hline 2 & Siklus II & $75,72 \%$ \\
\hline 3 & Peningkatan siklus I ke siklus II & $10,45 \%$ \\
\hline
\end{tabular}

Berdasarkan tabel 2, dapat dilihat bagaimana perbedaan aktivitas siswa dalam mengikuti pembelajaran denga model Number Head Together, dilihat dimana pada siklus I persentase aktivitas siswa hanya 65,27\% dan padasiklus II meningkat menjadi $75,72 \%$ dari hasil pengamatan terhadap aktivitas siswa terlihataktivitas siswa meningkat $10,45 \%$ yang dilakukan dua siklus. Hal ini sesuai dengan hasil penelitian Ulfaira dkk., (2014), perolehan persentase hasil observasi aktivitas siswa kriteria yang di peroleh adalah baik, dimana hasil observasi tersebut dilihat dari aktivitas siswa dan bagaimana guru mengelola dalam pembelajaran, penelitian ini dikatakan berhasil apabila kedua aspek tersebut telah berada dalam kategori baik.

\section{3) Pengelolaan Kelas}

Selain dari aktivitas siswa aktivitas guru juga memiliki perbedaan dalam setiap siklus dimana hasil dari perbedaan tersebut dapat di lihat dalam tabel 3.

Tabel 3. Hasil Keseluruhan Observasi Aktivitas Guru

\begin{tabular}{|l|l|c|}
\hline No & \multicolumn{1}{|c|}{ Siklus } & Persentase \\
\hline 1 & Siklus I & $72 \%$ \\
\hline 2 & Siklus II & $88 \%$ \\
\hline 3 & Peningkatan persentase & $16 \%$ \\
\hline
\end{tabular}

Berdasarkan tabel 3 tersebut dapat dilihat perbedaan hasil observasi bagaimana guru menerapkan model pembelajaran NHT terhadap siswa kelas XI MIA 2 MAN Siabu dimana diperoleh hasil pada siklus I aktivitas guru sudah sangat baik dimana pencapaiannya $72 \%$ sedangkan pada siklus ke 2 aktivitas guru 
PeTeKa (Jurnal Penelitian Tindakan Kelas dan Pengembangan Pembelajaran)

Vol 2 No 1 Tahun 2019 Hal 1-8

pun makin meningkat dimana aktivitas guru mencapai angka 88\%, hal ini seesuai dengan hasil penelitian Aulia dkk., (2018) mengatakan bahwa guru dapat menciptakan pengelolaan kelas yang efektif akan mempengaruhi kinerja akademik siiswa, dan mengakibatkan aktivitas dan hasil belajar siswa meningkat.

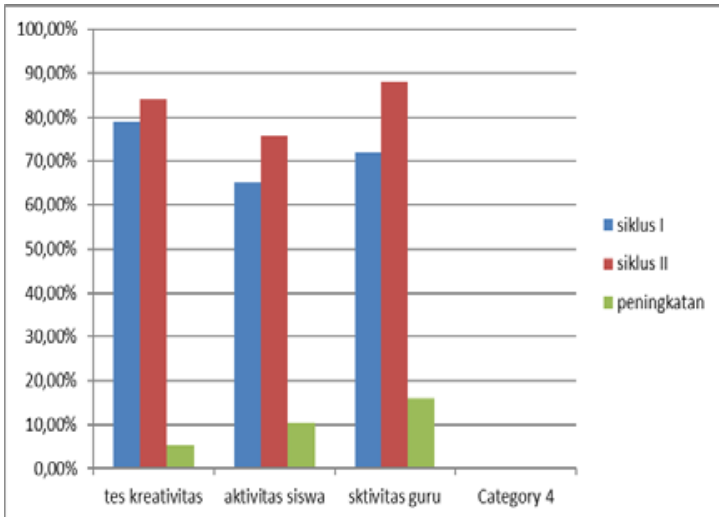

Gambar 6. Diagram Hasil Keseluruhan Hasil Penelitian

\section{SIMPULAN}

Berdasarkan hasil penelitian tindakan kelas yang telah dilakukan di kelas XI MIA 2 MAN Siabu diperoleh kesimpulan bahwa ada peningkatan kreativitas siswa dengan menggunakan model pembelajaran Number Head Together (NHT) sebesar 5,27\% dari Siklus I ke siklus II, ada peningkatan aktivitas siswaa melalui penerapan model pembelajaran Number Head Together (NHT) yang sangat signifikan di mana hasilnya mencapai angka persentasi 75,72\% dan masuk dalam kategori baik, peningkatan pengelolaan kelas oleh guru meningkat dari siklus I ke siklus II yaitu sebesar $16 \%$.

\section{DAFTAR PUSTAKA}

Adang, Heriawan. (2012). Metodologi Pembelajaran Kajian Teoritis Praktis. Banten: Perum Bumi Baros Chasanah

Aulia, R., dan U. T. Sontani. (2018). Pengelolaan Kelas Sebagai
Determinnan Terhadap Hasil Belajar, Jurnal Pendidikan Manajemen Perkantoran Vol .3 No. 2.

Khairunnisa, (2018). Peningkatan Kemampuan Siswa Dalam Membaca Teks Bahasa Inggris Melalui Permainan Postcard From Jhon Di Kelas VII Mts Muhammadiyah 22 Padangsidimpuan ; Jurnal Penddikan ISSN 2541 - 3775 Vol,3 No,1

Rachmawati, Yeni \& Euis Kurniati. 2005. Strategi Pengembangan Kreativitas Pada Anak Usia Taman Kanak-kanak. Jakarta : Depdikbud

Suryosubroto. (2009). Proses BelajarMengajar di Sekolah. Jakarta: RinekaCipta

Sulfiani, M. (2016). Peningkatan Kemampuan Pemahaman Melalui Strategis SQ3R Pada Siswa Kelas VII SMP 36 Makasssar. Vol. 9, No. 2, Hal 15-18.

Trianto. (2010). Model Pembelajaran Terpadu, Jakarta : Bumi Aksara.

Ulfaira, Jamaluddin Dan Septi Wiharti. (2014). Meningkatkan Aktivitas Belajar Pada Siswa Kelas III SD Marantale Dalam Pembelajaran PKN Melalui Penerapan Metode Pembelajaran Role Playing, ISSN,2354-614X, Jurnal Kreatif Tadulako Online Vol.3 no.3 